\title{
STUDENT PREFERENCES FOR CAREER MENTORING IN PROPERTY AND CONSTRUCTION
}

\author{
LIZ EVERIST, VALERIE FRANCIS \\ and \\ LYNNE ARMITAGE \\ The University of Melbourne
}

\section{ABSTRACT}

Although career mentoring is well established across many professional areas, its application in the field of property and construction is at an emergent stage. As part of ongoing quality review aimed at enhancing student engagement with their educational program, a survey was undertaken among first and second year students enrolled in the Faculty of Architecture, Building and Planning's Bachelor of Planning and Design (Property and Construction). The study investigated student preferences regarding involvement in a career mentoring program including mentoring program options and mentoring style preferences. Several differences emerged between property and construction student cohorts and in particular between male and female students. The findings demonstrate the importance of examining mentoring preferences from the perspective of the mentee.

Keywords: Mentoring, career, tertiary education, property and construction

\section{INTRODUCTION}

Whilst there is an extensive body of literature on the character and value of mentoring in general, the focus on career mentoring is very restricted, although Jacobi (1991) provides a comprehensive review of the literature relating to mentoring and academic progress. More characteristically, the varying definitions of mentoring offered in the articles on the topic generally combine career guidance with psycho-social support. See, for example, Allen, McManus and Russell (1999); Nelson and Quick (1991); Ragins and Cotton (1999); Eby (1997); Dreher and Ash (1990). 
Research in this area has identified two models of mentoring germane to this discussion one which has evolved in North America and the other in Europe - as identified by Klasen and Clutterbuck (2002). In North America, mentoring is closely aligned with sponsorship and implies a power relationship between the mentor and 'protégé'. A frequent characteristic of this type of relationship is that the mentor takes on more responsibility for the protégé's career advancement through coaching and advising.

By contrast, in the European model, the term 'developmental mentoring' has evolved. This gives more focus to the 'mentee' through a more independent approach to selfmanagement. The more experienced, though not necessarily more senior or more powerful, mentor is the facilitator rather than the coach. This model emphasises the mentee's responsibility to engage in the mentoring and posits that the role of the mentor is to facilitate and assist the mentee to process, challenge and assimilate their individual learning. One of the great advantages of this kind of mentoring is that it encourages the mentee's 'independence and self-reliance in the management of their own learning' (Klasen and Clutterbuck, 2002).

Both models have influenced the Australian concept of mentoring and, hence, it is considered appropriate to define mentoring in the context of career mentoring in higher education as 'help by one person to another in making significant transitions in knowledge, work or thinking' (Klasen and Clutterbuck, 2002).

\section{CONTEXT OF THE STUDY}

\section{Career mentoring at The University of Melbourne}

Career mentoring programs have been established at The University of Melbourne since 2001. Commencing in the Institute of Land and Food Resources and the School of Medicine, programs are now offered in six faculties (including the Faculty of Architecture, Building and Planning) through the Career Mentor Connection project. In 2004, a pilot mentoring program was offered to third year students in the property and construction stream of the Bachelor of Planning and Design.

The view of the Career Mentor Connection project (CMC) is that the key purpose of career mentoring is to assist students in their transition from study to the workplace. Third year property and construction students are preparing for their work experience year, when three years of theory and practice will be tested in the professional environment. Career mentoring provides an opportunity for the contextualisation of their learning through direct experience of the industry (Dutton, 2003) through the insights of their mentor.

The diversity of employment opportunities and the vocational nature of the property and construction degree means that it is essential for students to have practical insights into the 
direct application of their knowledge base in the context of their future workplace and that they are well informed when it comes to their career choices. Because career mentoring is based on real life experiences and personal knowledge, the mentor has the opportunity to expand the student's awareness, insight and perspective (Shea, 1992). Being a maledominated industry, it is hoped that appropriate career mentoring will also provide female students with access to the crucial networks and support that will predicate their retention and long-term success in the industry (Scandura, 1992). The authors are not aware of any literature referring specifically to the property and construction industry.

\section{Gender in mentoring}

In the property and construction environment, gender is an area of concern in recognition of the extreme gender imbalance in professional employment in favour of men. In 1991, Newell and Kincaid (1991) identified women as representing 3\% of the membership of the Australian Institute of Valuers and Land Administrators, but comprising enrolments ranging from $10 \%$ to $20 \%$ of students in property courses in Australian universities. Almost a decade and a half later, a substantial increase in female participation in the profession is evident: by 2005, the renamed Australian Property Institute reported a female membership for the three largest states (by number of members) - being New South Wales, Victoria and Queensland - of 15.5\%, $16.6 \%$ and $11.5 \%$ respectively from a total membership of 7449 (Allen, 2005). Over the period 2000 to 2005, female student enrolments at The University of Melbourne in the Bachelor of Planning and Design (Property and Construction) ranged from 31.4\% in 2002 to $40.8 \%$ in 2005 of total enrolments ranging from 220 to 262. Graduations during a similar period, 2000 to 2004 (the most recent annual figure currently available), ranged from a low of $25 \%$ in 2000 to a high of 42.3\% in 2002 (ABP, University of Melbourne 2005).

Recent research into mentoring has altered a previous trend by raising the profile of the issue of gender in mentoring relationships, in particular the consideration of difference between the degrees of psycho-social and career development mentoring provided in male/male, male/female, female/female and female/male partnerships (e.g. Soshik and Godshalk, 2000). To date, the literature has been contradictory in this regard, highlighting the need for more empirical research.

Smith, Smith and Markham (2000) questioned whether females are more likely to be involved in mentoring programs and discovered that the proportion of male mentors was higher, but that females were more highly represented as mentees - suggesting strong demand from this cohort. Although beyond the scope of this paper, it is interesting to note that other research has questioned whether mentoring programs do in fact assist minorities, given existing power hierarchies (Hansman, 2001; Kochran and Pascarelli, 2003). 


\section{Cross cultural mentoring}

This facet has been considered in recent research by Thomas (2001) in respect of issues of cross-cultural mentoring, in particular the mentoring of minorities. However no specific research has considered issues of international students with locally based mentors. It is anticipated that subsequent analysis of the data used for this study will provide the opportunity to pursue this very important avenue of investigation in the area of property and construction at a later date.

\section{Career mentoring}

Specifically, career mentoring is that aspect of mentoring which provides the experiential framework that enables mentees to transfer their academic learning to the workplace and also to retain that learning through reflection and then application (Dutton, 2003).

In addition, career mentoring offers effective opportunities for career enhancement in terms of considering career options, developing a career plan and then the tools to pursue this career plan. Research consistently reveals the benefits of career mentoring for the career development of employee-mentees in organisations and for trainee-mentees as part of their career progression (Sosik and Godshalk, 2000; Dutton, 2003; Doody, 2003).

In contrast, little research, particularly empirically based, discusses specifically the transition of vocational students into the professional workforce. This area needs to be tested more thoroughly to determine whether the benefits of improved networks, industryrelated skills and insights and access to a role model will still apply as strongly to the student-mentee experience as opposed to the employee-mentee relationship. There is also a dearth of research assessing how effectively career mentoring may assist studentmentees to enter the workforce feeling supported and motivated by a clear sense of direction and purpose, i.e. the psycho-social aspects of mentoring.

Benefits are not restricted to the mentees. Mentors also report many benefits in the literature, including recognition and increased professional profile, feeling challenged and the sharing of wisdom (Dutton, 2003). It can be a rewarding experience for the mentor learning from the mentee about new trends or reflecting on their own career (Klasen and Clutterbuck, 2002).

In the case of CMC, The University of Melbourne benefits through student satisfaction and retention, in creating functional links with industry, by preparing students appropriately for the workforce and ultimately by making them more employable.

\section{EMPIRICAL CONTEXT}

\section{Research aims}

This paper reports on the first stage of a career mentoring program which investigated the career mentoring preferences of property and construction students at The University of 
Melbourne. The justification for the original work of the CMC was to assist students to manage their progress through their undergraduate program as a result of perceived problems resulting from a lack of support. The lack of informal mentoring opportunities for students indicated a formal mentoring program was required; however, this still left scope for choice as to how the program should be approached. As current research consistently reinforces the view that effective mentoring programs require clear objectives (Klasen and Clutterbuck, 2002), this study aims to establish students' particular career mentoring style preferences and program preferences.

Whilst the structuring of the program was approached on the premise that no particular type of mentoring program was considered to be necessarily 'better' than another - each is appropriate for different situations (Saito and Roehlkepartain, 1992) - it was felt that, in order to provide the most effective career mentoring program for property and construction students, all student preferences needed to be identified and the subsequent program designed to take these into account.

In order to tailor programs to suit different cohorts of students, the preferences of male and female students and of local and international students were explored in respect of their preferred mentoring experience. These aspects have not, to the authors' knowledge, been considered in previous literature.

\section{METHODOLOGY}

\section{Data collection}

A questionnaire was distributed to undergraduate students enrolled in the first and second year of the Bachelor of Planning and Design (Property and Construction) (BPD (PC)) in the Faculty of Architecture, Building and Planning at The University of Melbourne in 2004. Participation in the survey was voluntary and the anonymity of respondents was ensured. The survey was administered to students during a scheduled lecture time. It was distributed by, and returned to, the first named author who had no involvement in course delivery or assessment.

\section{Survey}

Demographic information collected from each student included each respondent's gender, course (property or construction management), year of course and student residency status (local or international).

The first part of the survey sought to clarify the main goals students perceived to be most desirable in a career mentoring program, by offering a choice of topics and styles of interaction that ranged from the practical (i.e. 'finding work experience') to the psychosocial ('ongoing support and encouragement'). Students were asked to identify their preferences on 11 different aspects which had the potential to be included in a career 
mentoring program and they responded using a 5-point Likert type scale ranging from strongly disagree (1) to strongly agree (5). A higher value was indicative of greater support for that specific aspect within a mentoring program. An open-ended question was asked to confirm their preferences. In this question 'My ideal mentoring program would involve ...', students were asked to specifically write down two areas that were most important to them.

As mentoring programs can take a variety of forms, students were then asked about the mentoring style they would prefer. Various questions regarding different mentoring style were asked. These related to:

- One-to-one or group mentoring

- Regular, structured meetings or on an ad-hoc basis negotiated individually

- Meetings held either at the mentor's workplace or at other locations

- $\quad$ Preferred year program to be offered to students - from first to final year.

\section{RESULTS}

\section{The sample}

In total, 75 students responded to the survey, with $31 \%$ of respondents being female and $17 \%$ being international students. It is estimated the survey was distributed to 130 students and this high response rate of $58 \%$ was attributed to the collection method which was in class time. It is recognised that there may be 'non-response' bias in the survey results, as respondents are likely to be supportive of mentoring and, as such, the survey results may be over-estimates compared to a more random sample. Further information on the demographic composition of the sample is provided in Table 1. 
Table 1: Demographics of sample

\begin{tabular}{|l|l|l|l|l|l|}
\hline & $\mathbf{N}$ & $\mathbf{\%}$ & & $\mathbf{N}$ & $\mathbf{\%}$ \\
\hline Gender & & & Profile & & \\
\hline Male & 51 & 68.0 & Local & 61 & 81.3 \\
\hline Female & 23 & 30.7 & International & 13 & 17.3 \\
\hline Not specified & 1 & 1.3 & Not specified & 1 & 1.3 \\
\hline Year of course & & & & & \\
\hline $1^{\text {st }}$ year & 43 & 57.3 & Stream & & \\
\hline $2^{\text {nd }}$ year & 32 & 42.7 & Construction & 27 & 36.0 \\
\hline Undergraduate degree & & & Property & 38 & 50.7 \\
\hline Single degree & 62 & 82.7 & Not specified & 10 & 13.3 \\
\hline Dual degree & 13 & 17.3 & & & \\
\hline
\end{tabular}

\section{Mentoring program preferences}

The mentoring preferences of various cohorts of students can be found in Table 2. These results indicate that all program options were supported. When considering the sample as a whole, it is apparent that students consider 'Locating work/work experience' and 'Practical insights into the workplace' as a priority for a career mentoring program. Both items scored above 4.4 on a 5-point scale. 'Ongoing support and encouragement' and 'Involvement with other students across year levels' were not rated as highly - with scores below 3.8. It should be noted that most items scored above 4 and the average was 4.13 (SD = .466). When property and construction students were considered separately, their average scores were similar -4.10 for construction and 4.12 for property students. This indicates a strong perception of importance of most program items by the property and construction students in general.

When the gender and status of students was considered, it became apparent that male and female students, as well as local and international students, have different priorities. In all but one item ('Learning new 'job readiness skills'), females scored more highly than their male counterparts on all items and scored above 4.5 on the item 'Locating work/work experience'. The average was 4.26 for female and 4.09 for male students. An independent samples $t$-test revealed significant differences between male and female respondents on one item in particular: 'Ongoing support and encouragement', which was found to be significantly higher in the female sample ( $\mathrm{M}=4.17, \mathrm{SD}=.78)$ compared to the male sample $(\mathrm{M}=3.63, \mathrm{SD}=.82)$. 'Involvement with other students across year levels' approached significance for these cohorts. 


\begin{tabular}{|c|c|c|c|c|c|c|c|c|}
\hline \multirow{2}{*}{$\begin{array}{l}\text { I would prefer a mentoring } \\
\text { program which } \\
\text { would focus on: }\end{array}$} & \multicolumn{2}{|c|}{$\begin{array}{l}\text { TOTAL } \\
\text { SAMPLE }\end{array}$} & \multicolumn{2}{|c|}{$\begin{array}{l}\text { GENDER } \\
\text { (mean) }\end{array}$} & \multicolumn{2}{|c|}{$\begin{array}{c}\text { STUDENT } \\
\text { PROFILE } \\
\text { (mean) } \\
\end{array}$} & \multicolumn{2}{|c|}{$\begin{array}{l}\text { STREAM } \\
\text { (mean) }\end{array}$} \\
\hline & Mean & SD & Male & Fem. & Local & Int'l & Prop & CM \\
\hline $\begin{array}{l}\text { 1. Practical insights into the } \\
\text { workplace }\end{array}$ & 4.41 & .660 & 4.41 & 4.43 & 4.56 & 3.69 & 4.32 & 4.44 \\
\hline 2. Personal career development & 4.27 & .759 & 4.20 & 4.48 & 4.33 & 3.92 & 4.29 & 4.19 \\
\hline $\begin{array}{l}\text { 3. Networking within my } \\
\text { profession }\end{array}$ & 4.35 & .726 & 4.31 & 4.48 & 4.43 & 4.00 & 4.24 & 4.48 \\
\hline $\begin{array}{l}\text { 4. Ongoing support and } \\
\text { encouragement }\end{array}$ & 3.79 & .843 & 3.63 & 4.17 & 3.80 & 3.77 & 3.82 & 3.74 \\
\hline 5. Site visits or job shadowing & 4.04 & .851 & 4.04 & 4.05 & 4.12 & 3.69 & 3.89 & 4.15 \\
\hline $\begin{array}{l}\text { 6. Projects or tasks related to my } \\
\text { study }\end{array}$ & 4.05 & .804 & 4.00 & 4.17 & 4.13 & 3.77 & 3.89 & 4.07 \\
\hline $\begin{array}{l}\text { 7. Involvement with other } \\
\text { students across year levels }\end{array}$ & 3.51 & 1.095 & 3.31 & 3.91 & 3.48 & 3.77 & 3.63 & 3.33 \\
\hline $\begin{array}{l}\text { 8. Locating work/work } \\
\text { experience }\end{array}$ & 4.47 & .723 & 4.43 & 4.57 & 4.49 & 4.31 & 4.47 & 4.37 \\
\hline $\begin{array}{l}\text { 9. Help in exploring what I want } \\
\text { to do }\end{array}$ & 4.12 & .885 & 4.10 & 4.22 & 4.18 & 3.85 & 4.16 & 4.04 \\
\hline $\begin{array}{l}\text { 10. Learning new 'job readiness } \\
\text { skills' }\end{array}$ & 4.21 & .643 & 4.25 & 4.13 & 4.23 & 4.15 & 4.26 & 4.22 \\
\hline $\begin{array}{l}\text { 11. Finding out about the } \\
\text { diversity of job options }\end{array}$ & 4.28 & .727 & 4.27 & 4.30 & 4.34 & 4.00 & 4.37 & 4.07 \\
\hline
\end{tabular}

In considering the needs of local and international students, it should be noted that these results must be viewed with some caution due to the low sample size of international students. International students scored 4 or below on all items except 'Locating work/work experience' and 'Learning new 'job readiness skills'. The average was 4.19 for local students and 3.90 for international students. In all but one item ('Involvement with other students across year levels'), local students scored more highly on all items, indicating a greater perception of importance of most items by local students compared to their international colleagues. Whilst the difference for this particular item was not significant, an independent samples $t$-test revealed a significant difference between local and international students in one item: 'Practical insights into the workplace' was found to be a significantly higher priority for local students $(\mathrm{M}=4.56, \mathrm{SD}=.56)$ compared to international students $(\mathrm{M}=3.69, \mathrm{SD}=.63)$. 


\section{Bi-variate correlations}

In order to determine the nature and strength of linkages between the specific program aspects measured, bi-variate Pearson correlations analyses were conducted for the sample as a whole, and these are reported in Table 3. As can be seen, a large number of the career preference items are positively and significantly related to each other. It has been found helpful to consider the analysis of these items by segregating them as follows: Items 1,3 , 5, 6, 8 and 10 can be termed 'practical' and items 2, 4, 7, 9 and 11 are more related to career development and psycho-social elements.

In 12 out of 15 instances, there is significant correlation between the six items that are considered 'practical'. There is also significant correlation between the five items that are considered to be focussing on career development and psycho-social elements, except for one instance (out of 10 correlation results). These results show that students who are seeking practical assistance - for example 'networking' - are likely also to want exposure to 'site visits', 'work experience' and other practical components, whereas those preferring the 'ongoing support and encouragement'.

When the correlation of items termed 'practical' are considered with those termed 'psychosocial', there is some significant correlation in 13 instances at either the 0.01 or 0.05 level, but in 16 instances, the result is not significant. It is hard therefore to draw definitive conclusions. For example, there was a high correlation between preferences for 'career development' guidance and 'networking' (i.e. practical and psycho-social elements), but those preferring 'practical insights' were not at all interested in 'ongoing support and encouragement'. 
Table 3 : Bi-variate correlations of mentoring program preferences for whole sample

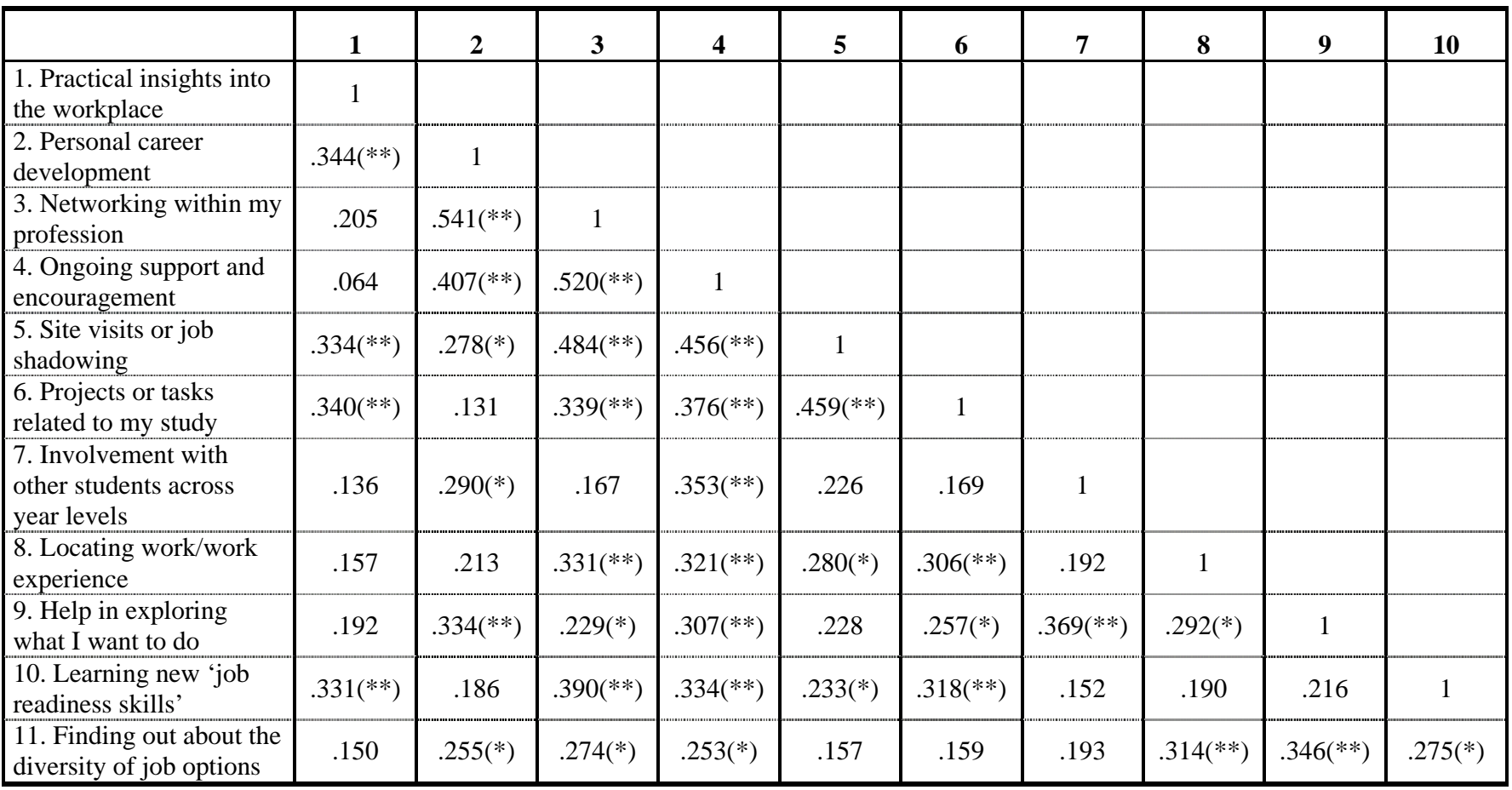

** Correlation is significant at the .01 level (2-tailed)

* Correlation is significant at the .05 level (2-tailed) 
It should be noted that an exploratory factor analysis was undertaken to examine the interrelationship between these career mentoring preference items. However, as a clear underlying structure was not revealed, the items were considered separately as presented in the above analyses.

\section{Ideal mentoring program}

Given the paucity of responses to the open-ended questions, the most interesting have been presented here in a discursive manner as no statistically significant outcome could be generated. Thirty eight of the 43 first year students and 19 of the 31 second year students responded to the open-ended question about their ideal mentoring program. Students were asked to indicate two important elements they would like included in their ideal mentoring program. A content analysis of the responses indicated six main themes were contained within the responses namely: networking, work experience, expectations and insights into the workplace, application of study or theory, career development support (including job readiness skills) and exploring the diversity of job options.

Issues around work experience and insights into the workplace were overwhelmingly the most dominant themes for all students. Over half of the female students indicated that finding work experience (including job readiness skills) was important to them. For example, a female second year property student wrote that her ideal mentoring program would include: 'Insights into the workplace and how to go about getting work experience'. The proportion of male students who nominated this issue as important was slightly lower than the female sample. A similar result was also found for the importance of 'expectations and insights' in career mentoring.

'Networking' was considered equally important by both male and female students with a similar proportion, about one quarter of each gender, noting this preference. A similar proportion of international students also felt that networking would be part of their ideal mentoring program. For instance, an international student wrote 'Networking is a most important element, especially in Asian countries'. A preference for 'career development and job readiness skills' ranked less highly, with around one fifth of respondents listing it as one of their two requirements. A slightly higher proportion of female students listed this option. For example, a female first year construction student wrote: 'Interview preparation and looking at broad job possibilities' as the preferences for her ideal mentoring program.

A similar proportion of male and female students were equally interested in finding out about the 'diversity of job options', but this option was identified by only one international student. 'Application of study or theory' was noted by a slightly higher proportion of males than females and also by one international student. A first year male construction student wrote: 'Job involvement with relevance to studies'. Surprisingly, 'ongoing support' was not mentioned as a preference by any student, which could be interpreted as a result of the concept of support being subsumed into the other thematic categories, particularly career development. 


\section{Mentoring style preferences}

Students were asked to indicate their preference for different styles of mentoring. This included questions regarding one-to-one mentoring, mentoring meetings, the location of the meetings and the timing of the mentoring within the course. The responses are summarized in Table 4.

Male students showed clearer preferences for the style of mentoring than females: $65.3 \%$ of male students preferred one mentor to one student; $87.8 \%$ preferred regular meetings; and $61.2 \%$ chose meetings at various locations over meeting at the mentor's office. Female students were more equally divided over the question of group or one-to-one mentoring and the location of meetings - although they did share the male students' preference for regular meetings (73.9\%), albeit less emphatically.

A slight majority of international students (53.8\%) chose one-to-one mentoring, as distinct from $62.7 \%$ of local students. Both clearly preferred regular meetings, $84.6 \%$ and $83.1 \%$ respectively. International students were also strong in their preference for meetings in various locations with $66.7 \%$ as against $57.1 \%$ of local students.

Construction students had a clearer preference for one-to-one mentoring than property students: $69.2 \%$ to $57.9 \%$. Both preferred regular meetings, property students rather more strongly with $89.5 \%$ compared to $73.1 \%$ of construction students. Construction students however were stronger about the location of meetings with $69.2 \%$, compared to $57.1 \%$ of property students, preferring various locations.

The choice of having a mentor in third year was the preferred option for all categories of respondents, particularly second year students (67.7\%). First year students were evenly divided about second or third year - 37.2\% each. 
Table 4: Mentoring style preferences by various student cohorts

\begin{tabular}{|c|c|c|c|c|c|c|c|c|c|}
\hline \multirow{2}{*}{ PREFERENCES } & \multirow{2}{*}{$A L L$} & \multicolumn{2}{|c|}{ GENDER } & \multicolumn{2}{|c|}{ PROFILE } & \multicolumn{2}{|c|}{ STREAM } & \multicolumn{2}{|c|}{$\begin{array}{l}\text { YEAR OF } \\
\text { COURSE }\end{array}$} \\
\hline & & Male & Female & Local & Int'l & $C M$ & Prop & 1st year & $\begin{array}{l}\text { 2nd } \\
\text { year }\end{array}$ \\
\hline \multicolumn{10}{|l|}{ Mentoring style } \\
\hline One mentor to one student & $60.3 \%$ & $65.3 \%$ & $52.2 \%$ & $62.7 \%$ & $53.8 \%$ & $69.2 \%$ & $57.9 \%$ & $65.1 \%$ & $53.3 \%$ \\
\hline $\begin{array}{l}\text { One mentor to group of } \\
\text { students }\end{array}$ & $39.7 \%$ & $34.7 \%$ & $47.8 \%$ & $37.3 \%$ & $46.2 \%$ & $30.8 \%$ & $42.1 \%$ & $34.9 \%$ & $46.7 \%$ \\
\hline \multicolumn{10}{|l|}{ Mentoring meetings } \\
\hline $\begin{array}{l}\text { Regular meeting e.g. } \\
\text { monthly }\end{array}$ & $83.6 \%$ & $87.8 \%$ & $73.9 \%$ & $83.1 \%$ & $84.6 \%$ & $73.1 \%$ & $89.5 \%$ & $100 \%$ & $61.3 \%$ \\
\hline $\begin{array}{l}\text { Ad hoc meetings e.g. as } \\
\text { needed }\end{array}$ & $16.4 \%$ & $12.2 \%$ & $26.1 \%$ & $16.9 \%$ & $15.4 \%$ & $26.9 \%$ & $10.5 \%$ & $0.0 \%$ & $38.7 \%$ \\
\hline \multicolumn{10}{|l|}{ Meeting location } \\
\hline Mentor's workplace & $40.6 \%$ & $38.8 \%$ & $47.4 \%$ & $42.9 \%$ & $33.3 \%$ & $30.8 \%$ & $42.9 \%$ & $42.5 \%$ & $37.9 \%$ \\
\hline $\begin{array}{l}\text { Various locations - as } \\
\text { negotiated }\end{array}$ & $59.4 \%$ & $61.2 \%$ & $52.6 \%$ & $57.1 \%$ & $66.7 \%$ & $69.2 \%$ & $57.1 \%$ & $57.5 \%$ & $62.1 \%$ \\
\hline \multicolumn{10}{|l|}{ Timing of mentoring } \\
\hline First year & $13.5 \%$ & $16.0 \%$ & $4.3 \%$ & $13.3 \%$ & $15.4 \%$ & $18.5 \%$ & $10.8 \%$ & $18.6 \%$ & $6.5 \%$ \\
\hline Second year & $24.3 \%$ & $20.0 \%$ & $34.8 \%$ & $23.3 \%$ & $23.1 \%$ & $18.5 \%$ & $29.7 \%$ & $37.2 \%$ & $6.5 \%$ \\
\hline Third year & $50.0 \%$ & $50.0 \%$ & $52.2 \%$ & $48.3 \%$ & $61.5 \%$ & $51.9 \%$ & $51.4 \%$ & $37.2 \%$ & $67.7 \%$ \\
\hline Fourth year & $4.1 \%$ & $6.0 \%$ & $0 \%$ & $5.0 \%$ & $0.0 \%$ & $3.7 \%$ & $2.7 \%$ & $2.3 \%$ & $6.5 \%$ \\
\hline Other combinations & $8.2 \%$ & $8.0 \%$ & $8.6 \%$ & $10.0 \%$ & $0.0 \%$ & $7.4 \%$ & $5.4 \%$ & $4.6 \%$ & $12.9 \%$ \\
\hline
\end{tabular}

\section{DISCUSSION}

With reference to the two models of mentoring discussed in the literature, the students have supported the adoption of the European 'developmental mentoring' model with their preferences. They have indicated a preference for mentoring that will enable them to consolidate and extend their own vocational learning, rather than seeking a reliance on the mentor to provide career coaching which is more usual in the North American model.

The results show that property and construction students are in favour of a practical mentoring program which emphasises insights into the workplace, finding work experience and generating opportunities for networking. This preference for activities providing exposure to industry indicates that the students' priority is to place their 
academic studies in the context of their future careers, as represented by the student who requested a program that involves 'finding out what goes on in the real world!'.

Finding personal career direction, while still important to students, is less of a priority. It is worth noting, however, that issues of career development and exploration of career options were rated slightly more strongly by female students than by male. Female students again scored slightly higher on the 'providing support and encouragement' option than male students although, overall, this option was not scored strongly by students. It is significant that none felt strongly enough to list this option as part of their ideal mentoring program'.

The differences between male and female, international and local, property and construction students indicate that their diverse needs should be recognised in the development of a career mentoring program. For example, international students are not a homogenous group but have many different backgrounds and subsequently diverse preferences for their mentoring.

As noted above, female students did have a slightly higher preference for career development and support and this may be a reflection of the male dominance of the industry. A career mentoring program for property and construction needs to be sensitive to these factors.

\section{CONCLUSIONS}

The results of this survey have identified student preferences in career mentoring and can now be used to support the further development of a career mentoring program in the property and construction context which is cognisant of student need. Preferences can be considered in the light of the diversity of student cohorts and any program will need to have sufficient flexibility to encompass the expectation of individual negotiation of activities and structures.

The preferences obtained will therefore enable the incorporation of the following elements which were viewed positively by the survey participants:

- One-to-one mentoring

- Regular meetings with a preference for some structure rather than none at all

- Meetings to be held at various locations - not just at the mentor's workplace

- Program to be offered in third year

In order to make the experience more congruent with the identified needs of the property and construction students, mentoring activities should incorporate the following, in order of priority: an emphasis on practical insights into the workplace; assistance with finding work experience, including job readiness skills; discussion of the diversity of job options; and consultation about career development opportunities. 
These preferences will also be used to identify clearer aims and objectives for the career mentoring program overall as well as in the property and construction context. As indicated earlier, clarity of purpose is essential for the success of mentoring programs as all participants benefit from a clearer understanding of their roles. By offering clarity of purpose, at the same time as meeting student needs, it is hoped to create the best possible career mentoring program for property and construction students.

In summary, the proposed objective of a career mentoring program for property and construction students would be: To facilitate students' transition into the workforce through practical exposure to the industry and career support.

On a practical note, it is apparent that different strategies are needed for different groups and feedback indicates that the CMC program was considered a very rewarding experience by those involved in this program (Everist, 2004). As a result, the program has again been run in the 2005 academic year with increased numbers of applicants seeking to be mentored and increased offers of mentoring support from many individual practising professionals in property and construction as well as support from two of the principal professional bodies - the Royal Institution of Chartered Surveyors and the Australian Property Institute. Some minor changes, based on the feedback received from students and mentors, have been incorporated for the 2005 program:

- Encourage mentors to enable students to follow a project through the period of the mentoring, for example, revisit a site over time, or follow through planning procedures, etc

- Suggest mentors discuss folio presentation, in terms of what employers are looking for rather than individual assessment

- Encourage mentors to assist the student to find work experience, not necessarily with their own firm but through industry contacts

- Share mentoring role with other colleagues, in particular students on their practical year or recent graduates

- $\quad$ Encourage more meetings earlier, in semester one.

It was apparent from the feedback that the effectiveness of one to one or group mentoring was reliant on the commitment of either the students or mentors, or both, rather than the dynamic of the partnership. Some mentors have asked for extra students in 2005, while others have requested one to one. In addition, some students felt that they would have preferred a group, while others found the logistics of groups quite difficult. A choice will therefore continue to be offered. However, where possible, students will be in groups of two rather than three to assist in planning meetings. Revised student application forms will place a greater emphasis on student commitment and this will be used in the selection 
process in 2005 (Everist, 2004). The University's commitment to the CMC program was underscored by the Vice-Chancellor's launch of the 2005 program.

\section{FURTHER RESEARCH}

Longitudinal survey analysis of this group of students will be undertaken, in their final year, comparing those who participated in the mentoring pilot program with those who did not. Pre- and post-program surveys of pilot program respondents will also provide separate data for analysis.

An extension of this research into the differences between property and construction students will also be beneficial, particularly in relation to their experiences of the mentoring pilot program. This analysis can be extended into related areas such as architecture and landscape architecture and complementary fields such as geomatics, engineering and commerce. With regard to international students, the value of sourcing career mentors in their home countries - instead of locally - needs to be investigated.

\section{REFERENCES}

Allen, T.D., McManus, S.E. and Russell, J.E. (1999) 'A newcomer socialization and stress: Formal peer relationships as a source of support', Journal of Vocational Behavior, Vol. 54, pp. 453-470.

Dreher, G. and Ash, R. (1990) 'A comparative study of mentoring among men and women in managerial, professional and technical positions', Journal of Applied Psychology, Vol. 75, pp. 525-535.

Dutton, C. (2003) 'Mentoring: the contextualisation of learning - mentor, protégé and organisational gain in higher education', Education and Training, Vol. 45, No. 1, pp. $22-$ 29.

Eby, L. T. (1997) 'Alternative forms of mentoring in changing organizational environments: A conceptual extension of the mentoring literature', Journal of Vocational Behavior, Vol. 51, pp. 125-144.

Everist L. (2004) 'Annual report of the 2004 CMC program in the Faculty of Architecture, Building and Planning', The University of Melbourne.

Ensher, E.A. (1997) 'Effects of race, gender, perceived similarity, and contact on mentor relationships', Journal of Vocational Behavior, Vol. 50, pp. 460-481.

Garvey, B. and Alred, G. (2000) 'Developing mentors', Career Development International, Vol. 5, pp. 216-222. 
Hansman, C.A. (2002) 'Diversity and power in mentoring relationships', Critical Perspectives in Mentoring: Trends and Issues, ERIC ACVE Information Series No. 388, pp. 39-48.

Jacobi, M. (1991) 'Mentoring and undergraduate academic success: A literature review', Review of Educational Research, Vol. 61, pp. 505-532.

Klasen, N. and Clutterbuck, D. (2002) Implementing Mentoring Schemes, ButterworthHeinemann, Oxford.

Kochran, F.K. and Pascarelli, J.T. (2003) 'Mentoring as transformation: Initiating the dialogue', Global Perspectives on Mentoring: Transforming Contexts, Communities, Cultures, Information Age Publishing, Connecticut.

Nelson, D. L. and Quick, J. C. (1991) 'Social support and newcomer adjustment in organizations: Attachment theory at work?', Journal of Organizational Behavior, Vol. 12, pp. 543-554.

Newell, G. and Kincaid, D. (1991) 'Women in the Australian property industry', The Valuer, Vol. 31, No. 8, pp. 578-580.

Ragins, B.R. (1997) 'Antecedents of diversified mentoring relationships', Journal of Vocational Behavior, Vol. 51, pp. 90-109.

Ragins, B.R. and Cotton, J.L. (1999) 'Mentor functions and outcomes: a comparison of men and women in formal and informal mentoring relationships', Journal of Applied Psychology, Vol. 84, pp. 529-550.

Ragins, B.R. and McFarlin, D.B. (1990) 'Perceptions of mentor roles in cross-gender mentoring relationships’, Journal of Vocational Behavior, Vol. 37, pp. 321-339.

Saito, R.N. and Roehlkepartain, E.C. (1992) 'Variety of programs meet needs of mentors and mentees', Source Newsletter.

Scandura, T. (1992) 'Mentorship and career mobility: an empirical investigation', Journal of Organisational Behaviour, Vol. 13, pp. 169-74.

Smith, J.W., Smith, W.J. and Markham, S.E. (2000) 'Diversity issues in mentoring academic faculty', Journal of Career Development, Vol. 26, pp. 251-262.

Snooks and Co. (2002) Style manual for authors, editors and printers, $6^{\text {th }}$ edn, John Wiley and Sons Australia Ltd, Canberra. 
Sosik, J.J. and Godshalk, V.M. (2000) 'The role of gender in mentoring: Implications for diversified and homogenous mentoring relationships', Journal of Vocational Behavior, Vol. 57, pp. 102-121.

The University of Melbourne (2005) 'Student records', Faculty of Architecture, Building and Planning.

Thomas, D.A. (2001) 'The truth about mentoring minorities: Race matters', Harvard Business Review, Vol. 79, No. 4, pp. 99-107. 